\title{
Analytical Techniques for the Determination of Erlotinib HCl in Pharmaceutical Dosage Forms by Spectrophotometry
}

\author{
M. MATHRUSRI ANNAPURNA*, B. VENKATESH and R. KRISHNA CHAITANYA \\ Department of Pharmaceutical Analysis \& Quality Assurance, \\ GITAM Institute of Pharmacy, GITAM University, Visakhapatnam, India \\ mathrusri2000@yahoo.com
}

Received 31 January 2014 / Accepted 20 February 2014

\begin{abstract}
Three simple, rapid and sensitive spectrophotometric methods were developed for the determination of Erlotinib hydrochloride in pharmaceutical formulations. Beer's law was obeyed over a concentration range $0.5-30 \mu \mathrm{g} / \mathrm{mL}$ in $\mathrm{HCl}$ and acetate buffer and $1-30 \mu \mathrm{g} / \mathrm{mL}$ in phosphate buffer. The linear regression equations were found to be $\mathrm{y}=0.0717 \mathrm{x}+0.0083, \mathrm{y}=0.0676 \mathrm{x}$ +0.0102 and $\mathrm{y}=0.0638 \mathrm{x}+0.0096$ in $\mathrm{HCl}$, acetate buffer and phosphate buffer respectively and the three methods were validated as per ICH guidelines.
\end{abstract}

Keywords: Erlotinib $\mathrm{HCl}$, Spectrophotometry, Validation

\section{Introduction}

Erlotinib $\mathrm{HCl}$ is chemically $N$-(3-ethynylphenyl)-6, 7-bis (2-methoxyethoxy) quinazolin-4amine (Figure 1) with molecular weight of $429.90 \mathrm{~g} / \mathrm{mol}^{1}$. Erlotinib specifically targets the epidermal growth factor receptor tyrosine kinase, which is highly expressed and occasionally mutated in various forms of cancer. It binds in a reversible fashion to the adenosine triphosphate (ATP) binding site of the receptor ${ }^{2}$. It is approved for the treatment of patients with locally advanced or metastatic non-small cell lung cancer which belongs to 4-anilinoquinazoline class of compounds ${ }^{3}$. Its monotherapy has demonstrated clinical activity in non-small cell cancer, head and neck cancer and ovarian cancer in Phase studies in $\mathrm{USA}^{4-6}$.

Erlotinib $\mathrm{HCl}$ was determined by different analytical techniques such as liquid chromatography-mass spectrometry ${ }^{7-11}$ and liquid chromatography ${ }^{12-16}$ methods in biological samples, Spectrophotometry ${ }^{17-19}$, spectrofluorimetry ${ }^{20-21}$, UPLC $^{22}$, HPTLC $^{23}$ and RP-HPLC ${ }^{24-30}$ in pharmaceutical formulations.

In the present study, three novel simple, rapid and cost-effective UV spectrophotometric methods were developed for the routine analysis of Erlotinib $\mathrm{HCl}$ in pharmaceutical formulations in $0.1 \mathrm{~N}$ hydrochloric acid (Method A), acetate buffer $\mathrm{pH} 4.0$ (Method B) and phosphate buffer pH 5.0 (Method C) and they are validated as per the ICH guideline ${ }^{31}$. 


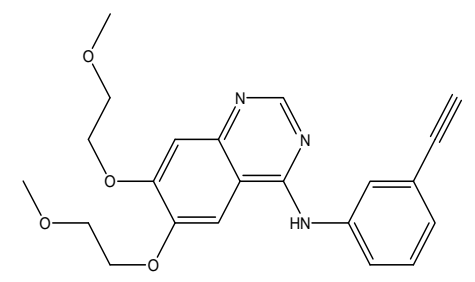

Figure 1. Chemical structure of Erlotinib $\mathrm{HCl}$

\section{Experimental}

A double beam UV-VIS spectrophotometer (UV-1800, Shimadzu, Japan) connected to computer loaded with spectra manager software UV Probe was employed with spectral bandwidth of $1 \mathrm{~nm}$ and wavelength accuracy of $\pm 0.3 \mathrm{~nm}$ with a pair of $10 \mathrm{~mm}$ matched quartz cells. For scanning, the wavelength range selected was $400 \mathrm{~nm}$ to $200 \mathrm{~nm}$ with medium scanning speed. All weights were taken using electronic balance (Denver, Germany). All experiments were performed at room temperature $(25 \pm 1)^{\circ} \mathrm{C}$.

\section{Reagents and chemicals}

Analytical grade reagents were used. Pure samples of Erlotinib $\mathrm{HCl}$ was kindly supplied as gift sample from Dr. Reddy's Labs (India) India. Erlotinib $\mathrm{HCl}$ is available commercially as tablets with brand names TARCEVA ${ }^{\circledR}$, ERLOCIP and TYROKININ $®$ (containing $100 \mathrm{mg}$ and $150 \mathrm{mg}$ of the drug content) respectively and twenty tablets from each brand were procured from the local market.

Preparation of hydrochloric acid $(0.1 \mathrm{~N})$ (Method A)

$8.5 \mathrm{ml}$ of conc. Hydrochloric acid was taken in a $1000 \mathrm{~mL}$ volumetric flask and diluted up to the mark with distilled water.

\section{Preparation of acetate buffer ( $p H$ 4.0) (Method B)}

$2.86 \mathrm{~mL}$ of glacial acetic acid and $1.0 \mathrm{~mL}$ of a 50 per cent solution of sodium hydroxide were taken in a $1000 \mathrm{~mL}$ volumetric flask, add diluted up to the mark with distilled water.

\section{Preparation of phosphate buffer ( $p H$ 5.0) (Method C)}

6.8 grams of potassium di hydrogen phosphate was taken in $1000 \mathrm{~mL}$ of water and adjusted $\mathrm{pH}$ to 5.0 with $10 \mathrm{M}$ potassium hydroxide.

\section{Preparation of stock solution}

Erlotinib $\mathrm{HCl}$ stock was prepared by dissolving $25 \mathrm{mg}$ of the drug in methanol in $25 \mathrm{~mL}$ volumetric flask $(1000 \mu \mathrm{g} / \mathrm{mL})$ and dilutions were made from the stock solution with hydrochloric acid, acetate buffer and phosphate buffer for method A, B and C respectively. The above solutions were scanned $(200-400 \mathrm{~nm})$ against their reagent blank and the absorption spectra were recorded for method A, B and C respectively.

\section{Linearity}

A series of drug solutions were prepared for method A, B $(0.5-30.0 \mu \mathrm{g} / \mathrm{mL})$ and $\mathrm{C}$ $(1-30 \mu \mathrm{g} / \mathrm{mL})$ and scanned $(200-400 \mathrm{~nm})$ against their reagent blank. The absorbance of the above solutions was noted from the absorption spectra recorded for the three methods A, B and $\mathrm{C}$ respectively and a calibration curve was plotted by taking the concentration of the solutions on the $\mathrm{x}$-axis and the corresponding absorbance on the y-axis. 


\section{Precision and accuracy}

The precision study was done by recording the absorbance of six replicates for method $\mathrm{A}, \mathrm{B}$ and $\mathrm{C}(20 \mu \mathrm{g} / \mathrm{mL})$ and the $\% \mathrm{RSD}$ was calculated. Accuracy was evaluated from the percent recovery studies by the addition of $80 \%, 100 \%$ and $120 \%$ of pure sample solution to the pre-analysed formulation solution. Erlotinib $\mathrm{HCl}$ extracted drug solution from the formulation $(10 \mu \mathrm{g} / \mathrm{mL})$ was spiked with $80 \%, 100 \%$ and $120 \%$ of pure API solution and the $\%$ recovery was calculated.

\section{Assay procedure for the commercial formulations}

Twenty tablets from each brand were procured from pharmacy store and extracted using methanol. The filtrate so obtained during the extraction was diluted further with hydrochloric acid, acetate buffer and phosphate buffer separately for method A, B and C respectively and the percentage recovery was calculated.

\section{Results and Discussion}

The absorption spectrum of Erlotinib in hydrochloric acid (Method A) has shown two $\lambda_{\max }$ values at 248.18 and $342.37 \mathrm{~nm}$ (Figure 2) but $\lambda_{\max } 342.37 \mathrm{~nm}$ was chosen for all the analytical determinations.

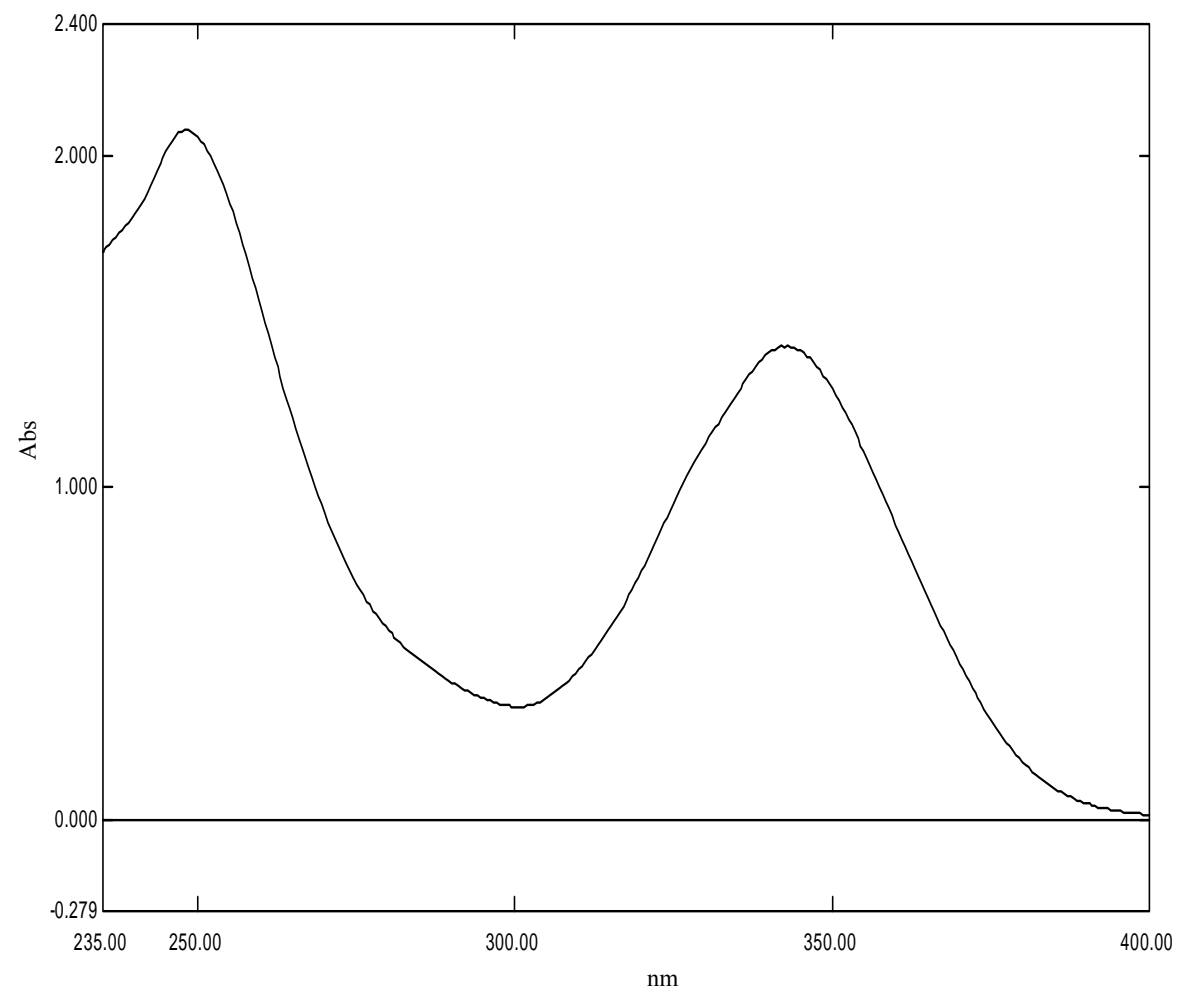

Figure 2. Absorption spectrum of Erlotinib in $\mathrm{HCl}(20 \mu \mathrm{g} / \mathrm{mL})$

Similarly the absorption spectrum of Erlotinib has shown $\lambda_{\max }$ at $342.40 \mathrm{~nm}$ in acetate buffer (Figure 3) (Method B) and at $\lambda_{\max } 340.94 \mathrm{~nm}$ in phosphate buffer (Figure 4) (Method C). 


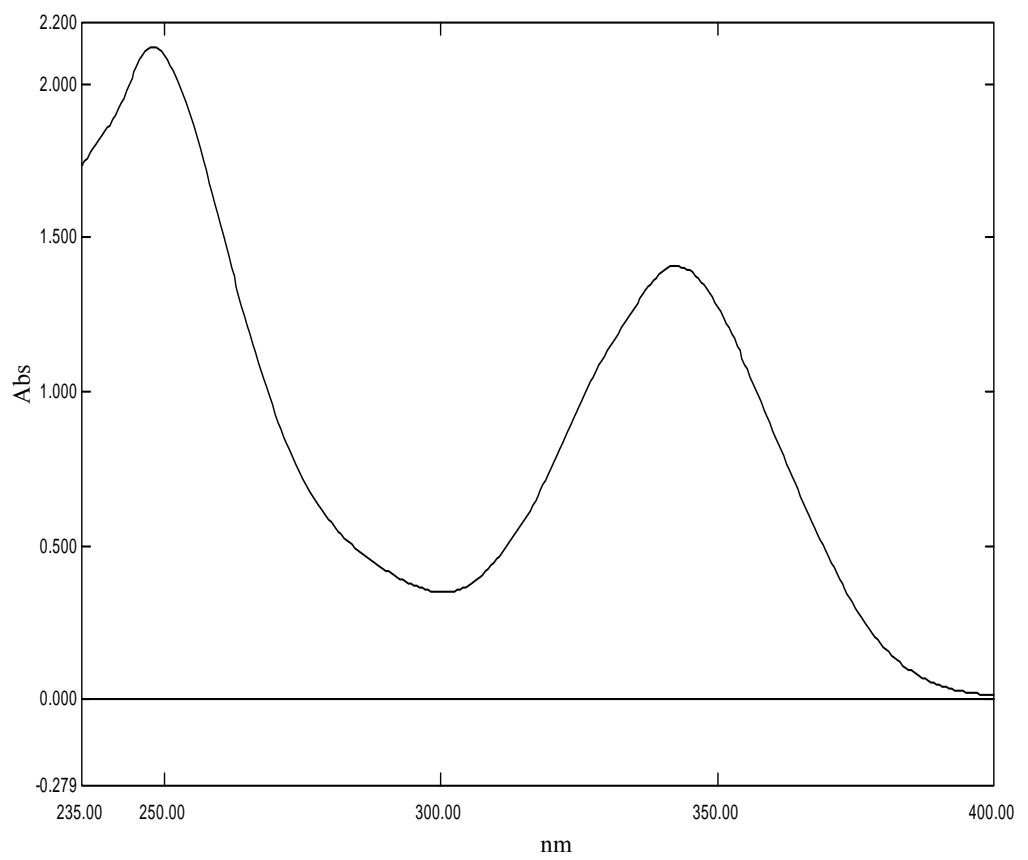

Figure 3. Absorption spectrum of Erlotinib in acetate buffer $(20 \mu \mathrm{g} / \mathrm{mL})$

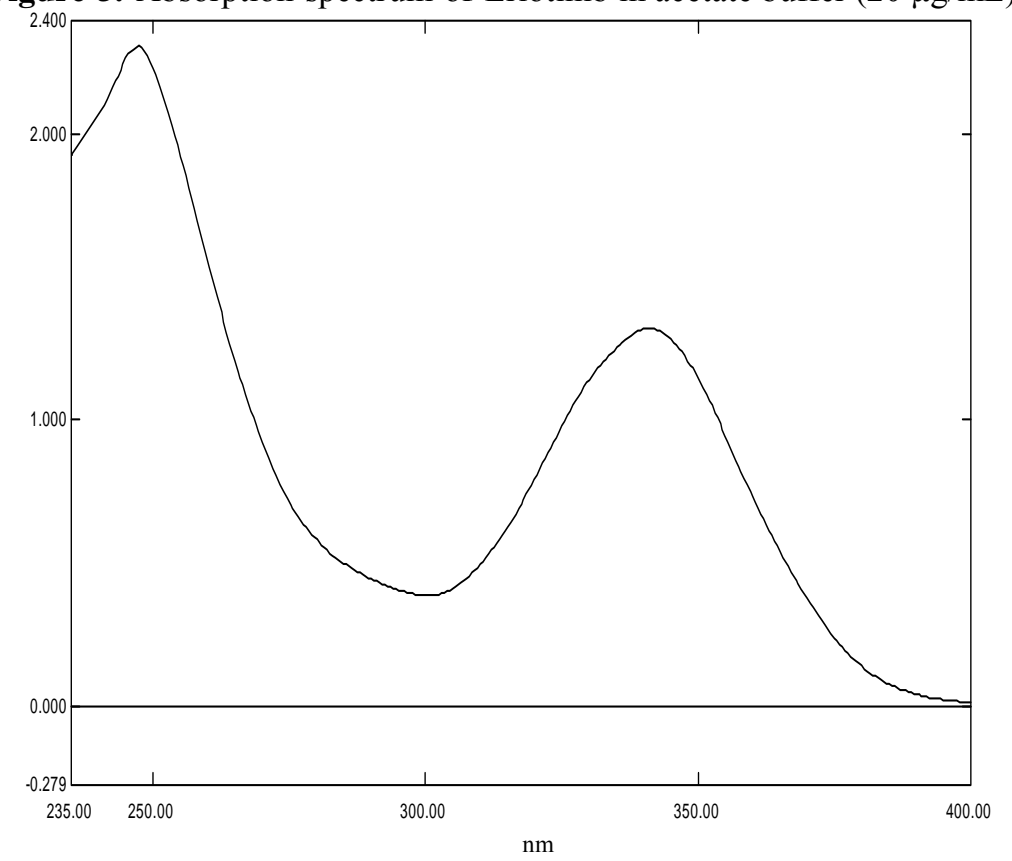

Figure 4. Absorption spectrum of Erlotinib in phosphate buffer $(20 \mu \mathrm{g} / \mathrm{mL})$

A graph was drawn by taking the concentration of the drug solutions on the $\mathrm{x}$-axis and the corresponding absorbance values on the $\mathrm{y}$-axis for the data obtained in method A, B and C and the calibration curves were shown in Figure 5. The linear regression equations were 
found to be $\mathrm{y}=0.0717 \mathrm{x}+0.0083\left(\mathrm{R}^{2}=0.9992\right), \mathrm{y}=0.0676 \mathrm{x}+0.0102\left(\mathrm{R}^{2}=0.999\right)$ and $\mathrm{y}$ $=0.0638 \mathrm{x}+0.0096\left(\mathrm{R}^{2}=0.999\right)$ in method $\mathrm{A}, \mathrm{B}$ and $\mathrm{C}$ respectively. The \% RSD in precision studies was found to be less than $2 \%$ in method $\mathrm{A}(0.23-0.56), \mathrm{B}(0.54-0.63)$ and $\mathrm{C}(0.38-0.68)$ indicating that the methods are more precise. The optical characteristics were shown in Table 1 .
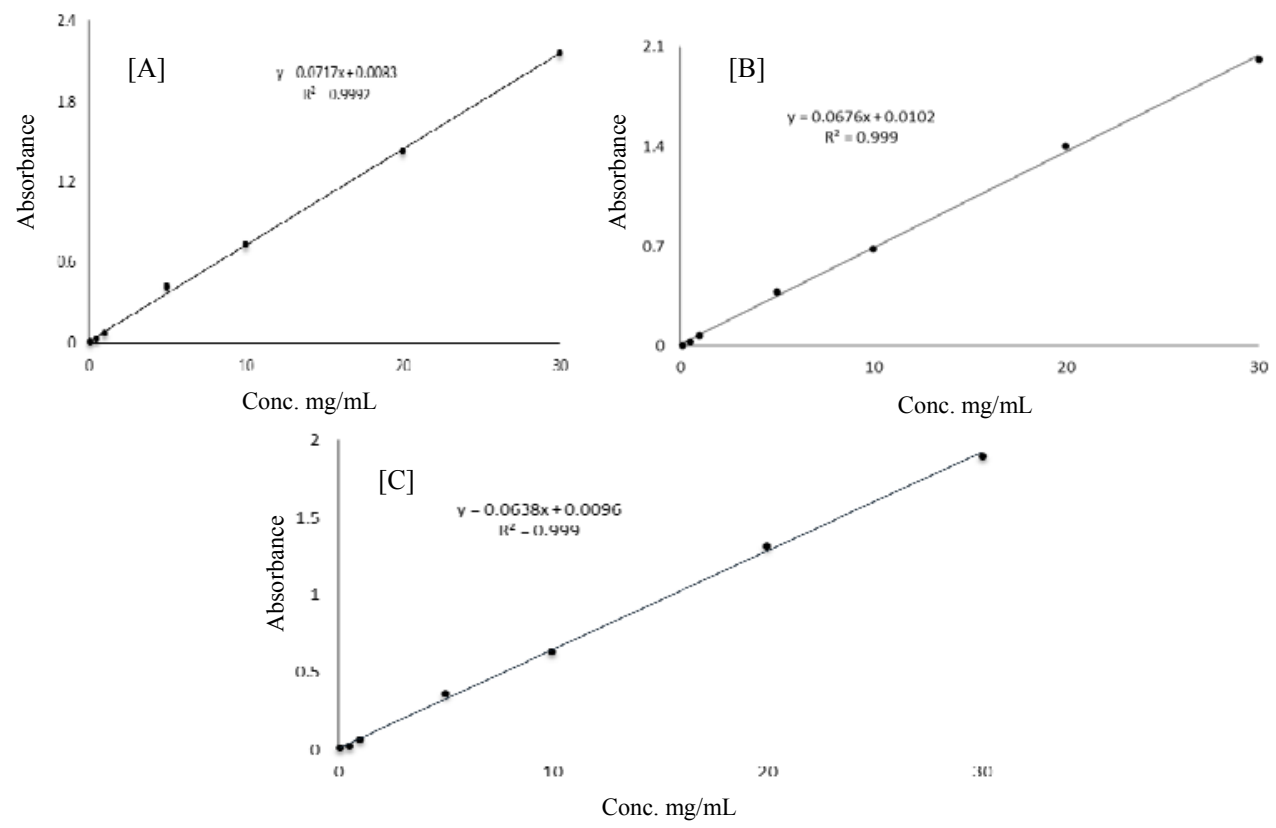

Figure 5. Calibration curves of Erlotinib in A) Hydrochloric acid B) Acetate buffer and C) Phosphate buffer

Table 1. Optical characteristics of Erlotinib $\mathrm{HCl}$

\begin{tabular}{lccc}
\hline \multicolumn{1}{c}{ Parameters } & Method A & Method B & Method C \\
\hline$\lambda_{\text {-max }}, \mathrm{nm}$ & 342.37 & 342.40 & 341.08 \\
Linearity range, $\mu \mathrm{g} / \mathrm{mL}$ & $0.5-30$ & $0.5-30$ & $1-30$ \\
Molar extinction coefficient & $3.13827 \times 10^{3}$ & $2.92332 \times 10^{3}$ & $2.738463 \times 10^{3}$ \\
$(\mathrm{~L} / \mathrm{mol} / \mathrm{cm})$ & & & \\
Sandell's sensitivity & 0.013699 & 0.014706 & 0.015699 \\
$\left(\mu \mathrm{g} / \mathrm{cm}^{2} / 0.001\right.$ Abs unit & & & \\
$/ 0.001$ Abs unit) & & & \\
Slope & 0.0717 & 0.0676 & 0.0638 \\
Intercept & 0.0083 & 0.0102 & 0.0096 \\
Correlation coefficient & 0.9992 & 0.999 & 0.999 \\
Precision (\%RSD) & & & \\
Intra-day (n=3) & 0.23 & 0.63 & 0.38 \\
Inter-day (n=3) & 0.56 & 0.54 & 0.68 \\
Accuracy (\% recovery) & $99.74-99.85$ & $99.46-99.91$ & $99.32-99.7$ \\
\hline
\end{tabular}

The $\%$ RSD in accuracy studies was also found to be less than 2.0 indicating that the methods are accurate. The percentage recovery was found to be $99.68-99.88,99.89-99.94$ and 99.84-99.89 for methods A, B and C respectively in marketed formulations (Table 2). 
Table 2. Analysis of Erlotinib $\mathrm{HCl}$ commercial formulation (Tablets)

\begin{tabular}{ccccccccccc}
\hline \multirow{2}{*}{ Brand } & $\begin{array}{c}\text { Labeled } \\
\text { amount } \\
\text { mg }\end{array}$ & \multicolumn{3}{c}{$\begin{array}{c}\text { Amount obtained } \\
\text { mg }\end{array}$} & \multicolumn{3}{c}{ \% Recovery } & \multicolumn{3}{c}{ \% RSD } \\
\cline { 3 - 12 } & & \multicolumn{3}{c}{ Method } & \multicolumn{3}{c}{ Method } & & & Method \\
\cline { 3 - 12 } & & A & B & C & A & B & C & A & B & C \\
\hline I & 100 & 99.68 & 99.89 & 99.84 & 99.68 & 99.89 & 99.84 & 0.32 & 0.42 & 0.68 \\
II & 100 & 99.88 & 99.92 & 99.86 & 99.88 & 99.92 & 99.86 & 0.55 & 0.39 & 0.31 \\
III & 100 & 99.83 & 99.94 & 99.89 & 99.83 & 99.94 & 99.89 & 0.49 & 0.28 & 0.55 \\
\hline
\end{tabular}

\section{Conclusion}

The proposed methods are simple, precise and accurate and can be applied for the determination of Erlotinib hydrochloride in pharmaceutical formulations successfully.

\section{Acknowledgment}

The authors are grateful to UGC, New Delhi for their financial support, M/s GITAM University for providing necessary research facilities and to Dr. Reddy's Labs (India) for providing the gift samples of the drug.

\section{References}

1. Martindale, The Extra Pharmacopeia, $31^{\text {st }}$ Edition, Reynolds J E F, (Ed) Royal Pharmaceutical Society, London, U.K, 2002, 465.

2. $\quad$ Raymond E, Faivre S and Armand J P, Drugs, 2000, 60(S1), 15-23.

3. Cohen MH, Johnson JR, Chen YF, Sridhara R and Pazdur R, Oncologist, 2005, 10, 461-466.

4. Gordon A N, Finkler N, Edwards R P, Garcia A A Crozier M, Irwin D H and Barrett E, Int J Gynecol Cancer, 2005, 15(5), 785-792; DOI:10.1111/j.1525-1438.2005.00137.x

5. Perez-Soler R, Chachoua A, Hammond LA, Rowinsky E K, Huberman M, Karp D, Rigas J, Clark G M, Santabarbara P and Bonomi P, J Clin Oncol., 2004, 22(16), 3238-3247; DOI:10.1200/JCO.2004.11.057.

6. Schilder R J, Sill M W, Lee Y C and Mannel R, Int J Gynecol Cancer, 2009, 19(5), 929-933; DOI:10.1111/IGC.0b013e3181a83467

7. Masters A R, Sweeney C J and Jones D R, J Chromatogr B., 2007, 848(2), 379-383; DOI:10.1016/j.jchromb.2006.10.046

8. Signor L, Varesio E, Staack R F, Starke V, Richter W F and Hopfgartner G, J Mass Spec., 2007, 42(7), 900-909; DOI:10.1002/jms.1225

9. Pan J, Jiang $X$ and Chen Y L, Pharmaceutics, 2010, 2(2), 105-118; DOI:10.3390/pharmaceutics2020105

10. Addepalli V Raju and Appala Raju Nemala, Am J Phytomed Clin Ther., 2013, 1(1), 83-97.

11. Satheeshmanikandan Thappali R S, Kanthikiran Varanasi, Sridhar Veeraraghavan, Rambabu Arla, Sandhya Chennupati, Madheswaran Rajamanickam, Swaroop Vakkalanka and Mukkanti Khagga, Sci Pharm., 2012, 80, 633-646.

12. Faivre L, Gomo C, Mir O, Taieb F, Schoemann-Thomas A, Ropert S, Vidal M, Dusser D, Dauphin A, Goldwasser F and Blanchet B, J Chromatogr B, 2011, 879(23), 2345-2350; DOI:10.1016/j.jchromb.2011.06.026

13. Wenjiang Zhang, Lillian L Siu, Malcolm J Moore and Eric X Chen, J Chromatogr B., 2005, 814(1), 143-147; DOI:10.1016/j.jchromb.2004.10.016 
14. Lepper E R, Swain S M, Tan A R, Figg W D and Sparreboom A, J Chromatogr B Anal Technol Biomed Life Sci., 2003, 796(1), 181-188.

15. Han Qing-Li, Ye Chen, Zai Quan Li, Chen Hui Deng, Liang Li, Shan Shan Bi, Meng Yao Li and Tian Yan Zhou and Wei Lu, J Chin Pharm Sci., 2011, 20(3), 245-252; DOI:10.5246/jcps.2011.03.030

16. Soheila Bolandnazar, Adeleh Divsalar, Hadi Valizadeh, Arash Khodaei and Parvin Zakeri Milani, Adv Pharm Bull., 2013, 3(2), 289-293.

17. Padmalatha M, Kulsum S, Rahul C, Reddy T M and Vidyasagar G, J Med Org Chem., 2011, 1(1), 26-30.

18. Mathrusri Annapurna M, Venkatesh B and Krishna Chaitanya R, Indo Amrican J Pharm Res., 2013, 3(11), 9270-9276.

19. Usha Rani G, Chandrasekhar B and Devanna N, J App Pharm Sci., 2011, 1(7), 176-179.

20. Rajesh V, Jagathi V, Sindhuri K and Devala Rao G, J Chem., 2011, 8(S1), S304S308; DOI:10.1155/2011/426452

21. Bivash Mandal, Pavan Balabathula, Nivesh Mittal, George C Wood and Himanshu Bhattacharjee, J Fluoresc., 2012, 22(6), 1425-1429; DOI:10.1007/s10895-012-1103-8

22. Naveen Kumar Reddy G, Rajendra Prasad V V S and Prashant Kumar Maharana, Der Pharma Chemica, 2012, 4(6), 2288-2297.

23. Rajesh V, Anupama B, Jagathi V and Varaprasad K, Int J Bio Med Res., 2011, 2(1), 433-435.

24. Ravi Kumar Konda, Sankara Babu K and Nagabhushanam C H, Int J Pharm Biomed Res., 2013, 4(1), 1-4.

25. Pujeri S, Khader A and Seetharamappa J, Anal Lett., 2009, 42(12), 1855-1867; DOI:10.1080/00032710903061170

26. Chandrashekara Karunakara, Udupi Aparna, Venkateshappa Chandregowda and Chandrasekara G Reddy, Anal Sci., 2012, 28(3), 305-308; DOI:10.2116/analsci.28.305

27. Gadekal Siva Sai Geetha, Raveendra Reddy J, Ramalingam P and Malleshwari P, Am J Pharm Tech Res., 2012, 2(5), 842-852.

28. Kalyana Chakravarthy V and Gowri Sankar D, RASAYAN J Chem., 2011, 4(2), 393-399.

29. Padmalatha M, Vanitha Prakash K, Kusum Syeda, Vishnu R, Wilson Kumar K and Vivekananda V, J Pharm Res., 2011, 4(3), 637-638.

30. Saravanan V S and Bojja Mallikarjuna Rao, J Drug Delivery Ther., 2013, 3(1), 50-54.

31. International Conference on Harmonization of Technical Requirements for the Registration of Pharmaceutical for Human Use: Validation of Analytical procedures, Text and methodology - Q2 (R1), 2005. 